\title{
Two new species of Gehyra (Squamata: Gekkonidae) geckos from the north-west Kimberley region of Western Australia
}

\author{
Paul Doughty, ${ }^{1,6}$, Russell Palmer ${ }^{2}$, Mark J. Sistrom ${ }^{3}$, \\ Aaron M. Bauer ${ }^{4}$ and Stephen C. Donnellan ${ }^{3,5}$ \\ ${ }^{1}$ Department of Terrestrial Zoology, Western Australian Museum, 49 Kew St, Welshpool, \\ Western Australia, 6016, Australia. \\ 2 Department of Environment and Conservation, PO Box 51, Wanneroo, \\ Western Australia 6946, Australia. \\ ${ }^{3}$ Australian Centre for Evolutionary Biology and Biodiversity, University of Adelaide, Adelaide, \\ South Australia, 5000, Australia. \\ ${ }^{4}$ Department of Biology, Villanova University, Villanova, Pennsylvania, 19085, U.S.A. \\ ${ }^{5}$ South Australian Museum, North Terrace, Adelaide, South Australia, 5000, Australia \\ ${ }^{6}$ corresponding author - Paul.Doughty@museum.wa.gov.au
}

\begin{abstract}
Recent surveys in the Kimberley region of Western Australia have provided new material to reassess species diversity in the gecko genus Gehyra. Here we focus on morphological and molecular genetic variation within the G. occidentalis and G. xenopus groups. We first describe a new small-bodied species that has a wedge of granules between the lamellae on the basal part of the toe pads, similar to that seen in G. xenopus. This new species has a dorsal pattern comprising transverse rows of dark and light spots or lines on a dull reddish-brown background and genetically is not closely related to G. xenopus. The second new species is supported as closely related to G. occidentalis, but differs by being smaller in body size and having more than 40 precloacal and femoral pores in adult males, darker background colouration and pattern with thick dark lines and pale spots or bars (v. large dark and pale spots). These findings further add to the large number of endemic species known from the rugged, high rainfall zone of the north-west Kimberley.
\end{abstract}

KEYWORDS: Kimberley islands, lizard, Mitchell Plateau, mitochondrial DNA, monsoon tropics, ND2, Prince Regent River, saxicoline

\section{INTRODUCTION}

Geckos from the genus Gehyra (Gekkonidae) have long been a problematic group owing to interspecific morphological conservatism coupled with wide variation within some species complexes (Mitchell 1965; King 1983a, 1983b; Bauer and Henle 1994). When morphological variation in chromosomes was first investigated in the 1970s and 1980s, researchers found that chromosome types could vary widely within several species, indicating cryptic diversity (King 1979; Moritz 1986). However, recent progress using primarily DNA sequencing has been made towards delimiting species (Horner 2005; Sistrom et al. 2009) and placing Gehyra in a global context (Oliver et al. 2010b; Heinicke et al. 2011). The genetic studies done from tissues of recently collected specimens, in combination with detailed examination of larger series of specimens and exploration of poorly collected areas in Australia and the Pacific, have greatly facilitated these advances.

Prior to our study, six species of Gehyra were recognised from the Kimberley region of Western Australia: G. australis Gray, 1845; G. koira Horner, 2005 (with two subspecies, G. koira koira and G. koira ipsa); G. nana Storr, 1978; G. occidentalis King, 1984; G. pilbara Mitchell, 1965; and G. xenopus Storr, 1978. Recent surveys of the Kimberley have focussed on the topographically rugged north-western region which receives significantly higher summer rainfall than the rest of the Kimberley. In addition, the north-west Kimberley is partly isolated from the Top End and Arnhem Land escarpment by extensive areas of lowlying savannahs (Bowman et al. 2010) and from the 
rocky Pilbara region to the south by the Great Sandy Desert (Doughty et al. 2011). These factors combine to yield an area supporting a large endemic fauna, comprised in part of ancient lineages maintained by the region's role as a moist refugia during arid times, and in part of groups of varying age that have undergone speciation in situ (Cracraft 1991; Slatyer et al. 2007; Powney et al. 2010; Doughty 2011; Köhler 2011).

Recent collections of Gehyra specimens by the Western Australian Museum (WAM) and the Department of Environment and Conservation, Western Australia (DEC) in the Kimberley have focussed on the wetter north-west region including the near shore islands, the Prince Regent River Nature Reserve and Mitchell Plateau. Among the collections are diminutive geckos that superficially resemble G. nana but share with $G$. xenopus the wedge of granules on the digits. Also encountered were individuals similar to $G$. occidentalis but that are darker and smaller, with males possessing numerous pores on the thighs, and are well represented in collections from the Bonaparte Archipelago in the north-west Kimberley, but also from scattered sites on the mainland, generally within $100 \mathrm{~km}$ of the coast.

In this paper we focus on specimens that would have been generally referable to G. occidentalis or G. xenopus from the Kimberley region (Figure 1). Gehyra xenopus (up to $80 \mathrm{~mm}$ snout-vent length [SVL]) is characterised by the presence of a distinctive wedge of granules at the base of the toe pad that divides the proximal lamellae, a unique feature within Gehyra (Storr 1978; Storr et al. 1990; Cogger 2000). Gehyra occidentalis was described by King (1984a) using chromosomal evidence coupled with a morphological appraisal and comparisons with G. australis and G. pamela King, 1982. It is a mediumsized species (up to $70 \mathrm{~mm}$ SVL) with a general appearance that overlaps that of other taxa from the region. Accordingly, DNA sequence data indicate a high proportion of misidentifications associated with this taxon, including G. nana, G. pilbara and juveniles of larger species (Sistrom et al. 2012). Our review is therefore timely, as no work has been done on these taxa for decades. Here we assess molecular genetic and morphological variation within these groups, and we describe two new species of Gehyra from the northwestern Kimberley.

\section{METHODS}

\section{MATERIAL EXAMINED}

For the morphological assessment, we examined specimens from the collections of the WAM, including all type material, and registration numbers and collection information is presented in the type lists and in Appendix 1. For the genetic analyses, most material was also from the WAM with some samples from the South Australian Museum (SAMA; see Appendix 2). Genotyped holotypes and paratypes are indicated with an asterisk in the type lists. We combined the novel genotypes with the data of Sistrom et al. (2009) for comparison (specimen details are reported there).

\section{MOLECULAR GENETICS}

The nucleotide sequence of the mitochondrial $N A D H$ dehydrogenase subunit 2 (ND2) gene and partial sequence of the flanking $t R N A^{T R P}$ gene was determined for 63 individuals of Gehyra from the Kimberley (Appendix 2) and compared with sequences representing all currently recognised species of Gehyra from Australia, four species from Oceania and Melanesia and three outgroups from the genera Cyrtodactylus, Hemiphyllodactylus and Lepidodactylus available from Sistrom et al. (2009). DNA was extracted from frozen and alcohol preserved liver tissue using a Puregene ${ }^{\mathrm{TM}}$ DNA Isolation Tissue Kit D-7000a (Gentra Systems) following the manufacturer's guidelines. ND2 and partial flanking $t R N A$ were amplified using the primers M112F (5' - AAGCTTTCGGGGCCCATACC - 3') and M1123R (5' - GCTTAATTAAAGTGTYTGAGTTGC - 3') designed in the flanking methionine and alanine $t R N A \mathrm{~s}$. Amplifications were carried out in $25 \mu \mathrm{L}$ volumes using standard buffer and $\mathrm{MgCl}_{2}$ concentrations, $0.1 \mathrm{mM}$ each $\mathrm{dNTP}, 0.2 \mu \mathrm{M}$ each primer, 0.75 U AmpliTaq Gold ${ }^{\circledR}$ DNA Polymerase (Applied Biosystems) and approximately $100 \mathrm{ng}$ of genomic DNA. Thermocycler profiles were: $9 \mathrm{~min}$ at $94^{\circ} \mathrm{C}$, then 35 cycles of: $45 \mathrm{~s}$ at $94^{\circ} \mathrm{C}, 45 \mathrm{~s}$ at $60^{\circ} \mathrm{C}$ and $1 \mathrm{~min}$ at $72^{\circ} \mathrm{C}$ for $1 \mathrm{~min}$ with a final extension step of $6 \mathrm{~min}$ at $72^{\circ} \mathrm{C}$. The PCR product was purified using a Millipore Montage $\AA$ PCR384 Cleanup Kit (Millipore Corporation) following the manufacturer's guidelines. One microlitre of purified product was used as template for a BigDye Terminator sequencing reaction, which was carried out in $20 \mu \mathrm{L}$ reactions, consisting of $1 \mu \mathrm{L}$ of BigDye (Applied Biosystems), $7 \mu \mathrm{L}$ of $2.5 \mathrm{x}$ buffer and $1 \mu \mathrm{L}$ of 5 $\mathrm{pmol} / \mu \mathrm{L}$ primer. Sequenced products were separated on an Applied Biosystems 3730xl capillary sequencer. We obtained both forward and reverse sequences for each PCR product.

The protein-coding region of ND2 was translated into amino acid sequences using the vertebrate mitochondrial genetic code and was compared to Gekko gecko (GenBank accession EU054288) translations to check for unexpected stop codons and frame shifts. Sequence alignments were carried out using Geneious version 5.5.2 (Drummond et al. 2008). GenBank accession numbers for the ND2 sequences are JX524068JX524130.

\section{PHYLOGENETIC ANALYSES}

Phylogenetic analyses used maximum likelihood (ML) and Bayesian methods. Aligned sequences were partitioned according to codon position and Modeltest version 3.06 (Posada and Crandall 1998) was used to evaluate different models of nucleotide substitution. The model $\mathrm{GTR}+\mathrm{I}+\mathrm{G}$ was selected for all codon positions. ML analysis with 100 bootstrap replicates 


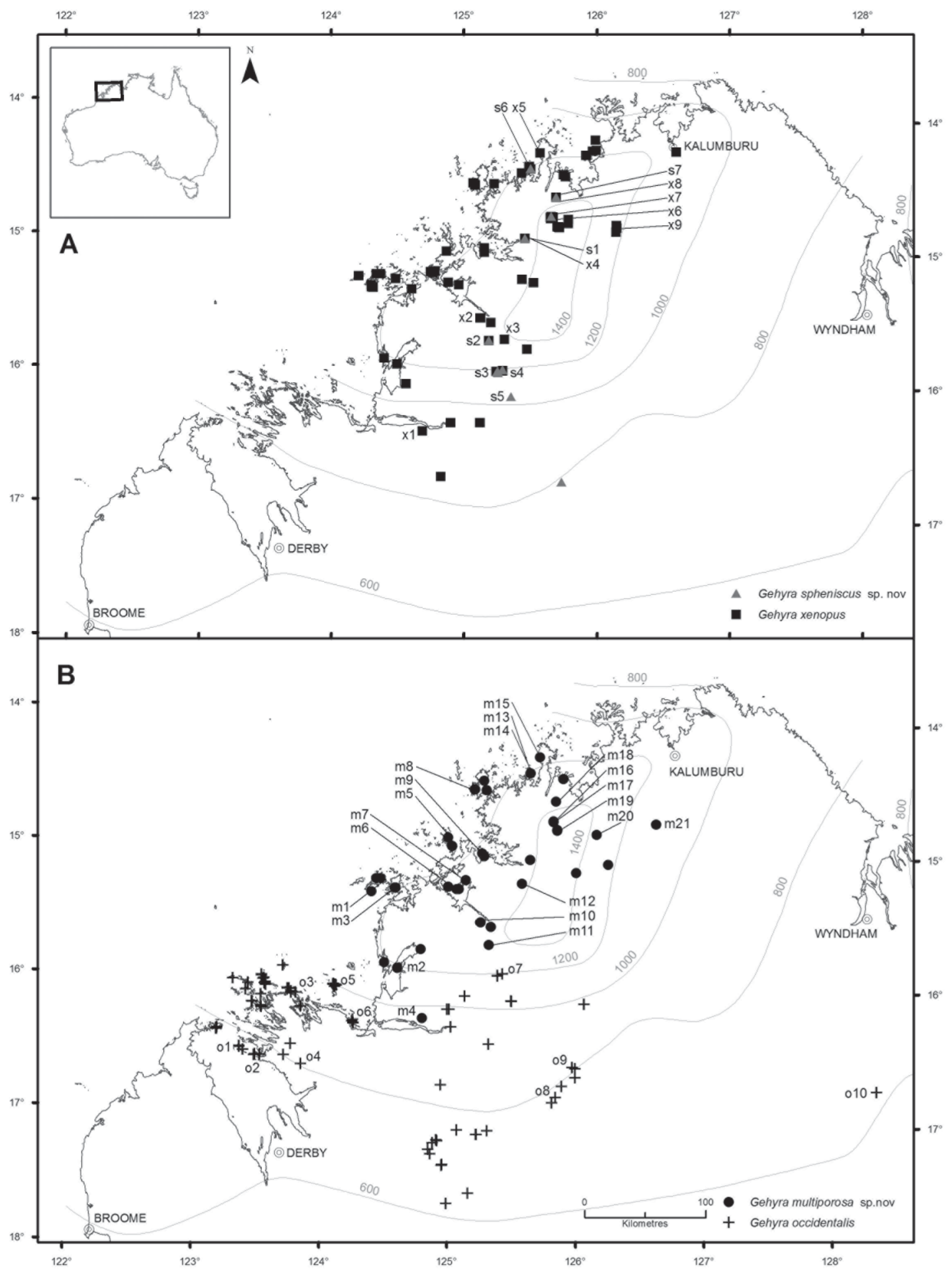

FIGURE 1 Distribution of Gehyra geckos allied to G. occidentalis and G. xenopus in the Kimberley region, Western Australia. Numbered points indicate genotyped specimens (see Figure 2). A) Gehyra xenopus - squares, x1-9; G. spheniscus sp. nov. - triangles, s1-7; B) G. occidentalis - crosses, o1-10; G. multiporosa sp. nov. - circles, m1-21. 
was carried out using the RAxML BlackBox web server (Stamatakis 2006; Stamatakis et al. 2008). Bayesian analysis was conducted using MrBayes version 3.1 (Ronquist and Huelsenbeck 2003). Data were partitioned for each codon position and branch lengths unlinked. Convergence was assessed from multiple runs and plots of likelihood against generation. For the final analysis, 5 million MCMC chains were run, sampled every 100 generations, with the first 5000 samples discarded as burn-in, leaving 95,000 trees for construction of a majority rule consensus. Convergence was assessed from the effective sample size for each parameter and from inspection of plot of likelihood against MCMC generation using Tracer version 1.5 (Rambaut and Drummond 2007).

\section{MORPHOLOGY}

Morphological characters (Table 1) were measured with a digital calliper to the nearest $0.1 \mathrm{~mm}$, except SVL and TailL that were measured with a rule to the nearest 0.5 and $1.0 \mathrm{~mm}$, respectively. Scale counts (e.g. labial scales, subdigital lamellae) were also scored (see Table 1). Notes on reproduction for females were made to assess whether taxa laid one or two eggs, but few females were gravid.

\section{RESULTS}

\section{MOLECULAR GENETICS}

The final alignment comprised 1057 base pairs (bp) and included $1023 \mathrm{bp}$ of ND2 and $34 \mathrm{bp}$ of $t R N A^{T R P}$. Figure 2 shows a ML phylogram of relationships among mitochondrial ND2 nucleotide sequences from 63 Gehyra, allied to G. occidentalis and G. xenopus, from north-western Australia. These geckos fell into four main groups, two allied with $G$. xenopus (typical xenopus and smaller, dark form xenopus) and two allied with G. occidentalis (typical occidentalis and dark, small form occidentalis). Three of the groups received strong support from ML bootstrap proportions and Bayesian posterior probabilities, but monophyly of the fourth (typical $G$. occidentalis) did not receive strong support in either the ML (bootstrap proportion - 67\%) or Bayesian (posterior probability - 0.81) analyses. In the typical occidentalis group, samples from Yampi Sound (o1-o4) formed a well supported sister group to the remaining samples that, in addition, formed two well supported subgroups: o5 and o6-o10. Within the latter subgroup, individuals from Mt Nyulasy (o10) clustered to the exclusion of o6-09, but this arrangement did not receive strong support. Net genetic divergence $\left(\mathrm{D}_{\mathrm{A}}-\mathrm{Nei}\right.$ 1987 ) between the two forms allied with $G$. occidentalis was $6 \%$, and between the two forms allied with $G$. xenopus was $14 \%$, which is comparable for some other sister species pairs of Gehyra (e.g. 14\% for G. catenata and G. dubia, and 10\% for G. minuta and G. variegata).

\section{MORPHOLOGY}

Examination of specimens revealed diagnostic characters that differed among the four major mitochondrial lineages (Table 1 and Taxonomy section, below). For the two lineages that possess a wedge of granules at the base of the toe pads (G. xenopus s.1.), body size differed dramatically with a maximum of 46 v. $77 \mathrm{~mm}$ SVL (Figure 3). Dorsal pattern and several additional morphological characters also differed between the two lineages. Figure 4 shows the toe pads of all taxa considered here, and although the wedge of granules is present in G. xenopus and the new taxon, the latter has fewer lamellae. Storr's (1978) description

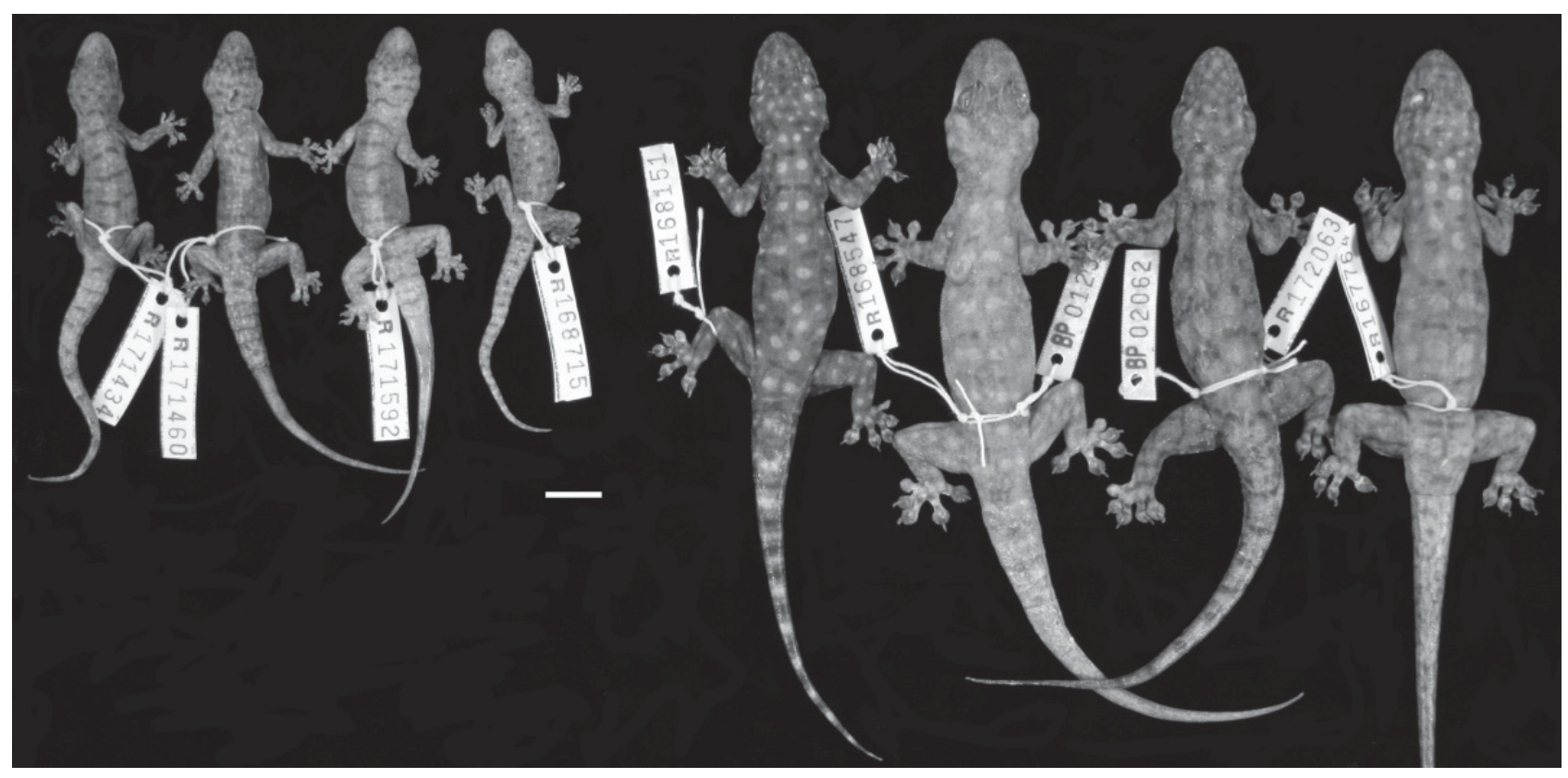

FIGURE 3 Variation between Gehyra spheniscus sp. nov. paratypes (left) and G. xenopus (right). Scale bar $=1 \mathrm{~cm}$. 


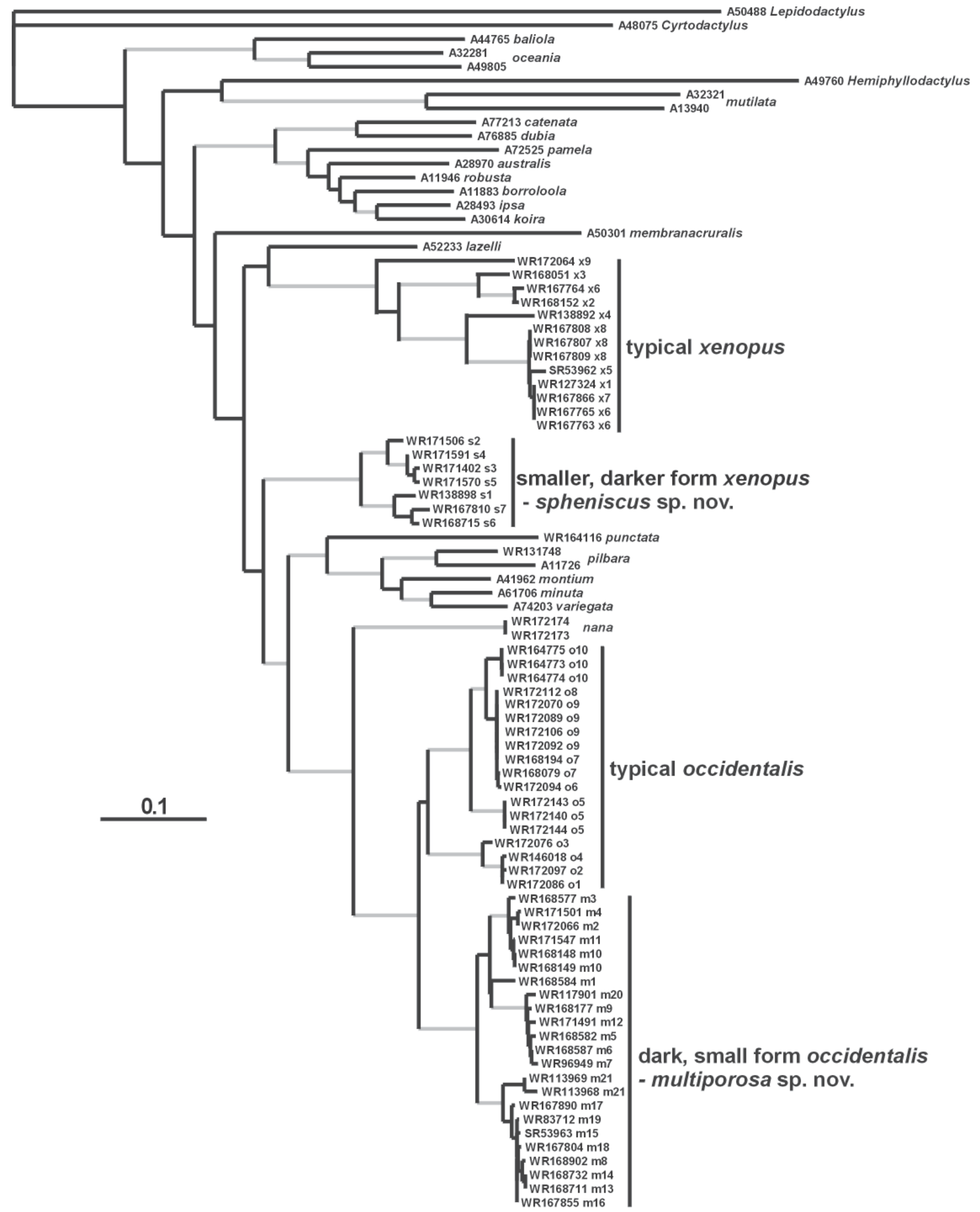

FIGURE 2 Maximum likelihood phylogram of relationships among mitochondrial ND2 nucleotide sequences from Gehyra geckos. Branches in grey denote bootstrap support $>70 \%$ and Bayesian posterior probabilities $>0.95$. Codes after specimen voucher numbers in the four clades allied with G. occidentalis and G. xenopus refer to localities indicated in Figure 1. Key: A - specimens from the South Australian Museum (Adelaide); WR - specimens from the Western Australian Museum. 


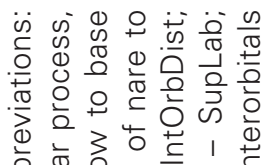

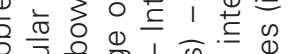

元

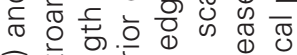

कु

Q

प्र

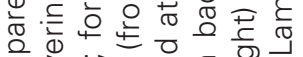

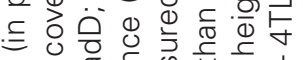

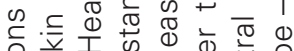

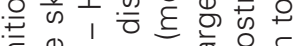

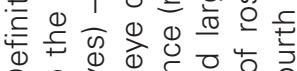

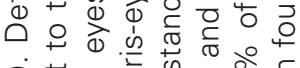

बिं

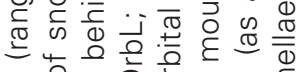

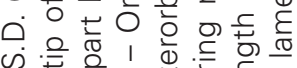

की

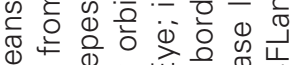

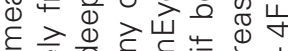

ब이의

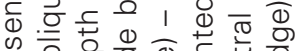

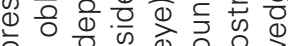

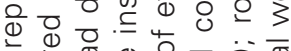

⿻

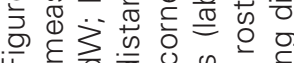

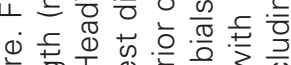

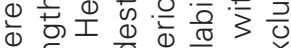

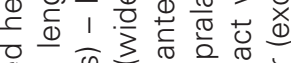

ब

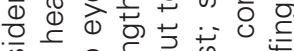

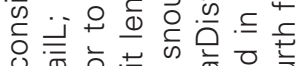

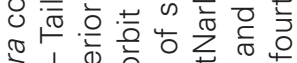

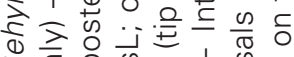

ه

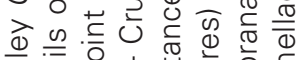

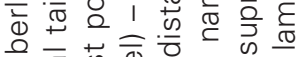

है.

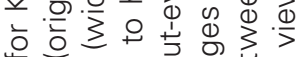

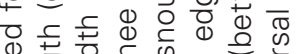

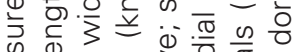

更

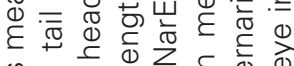

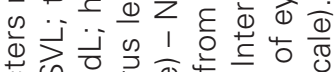

的西 $\overline{0} 0$

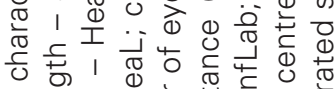

ত্

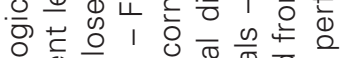

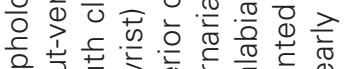

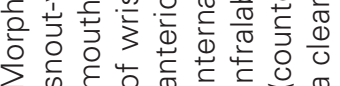

荘

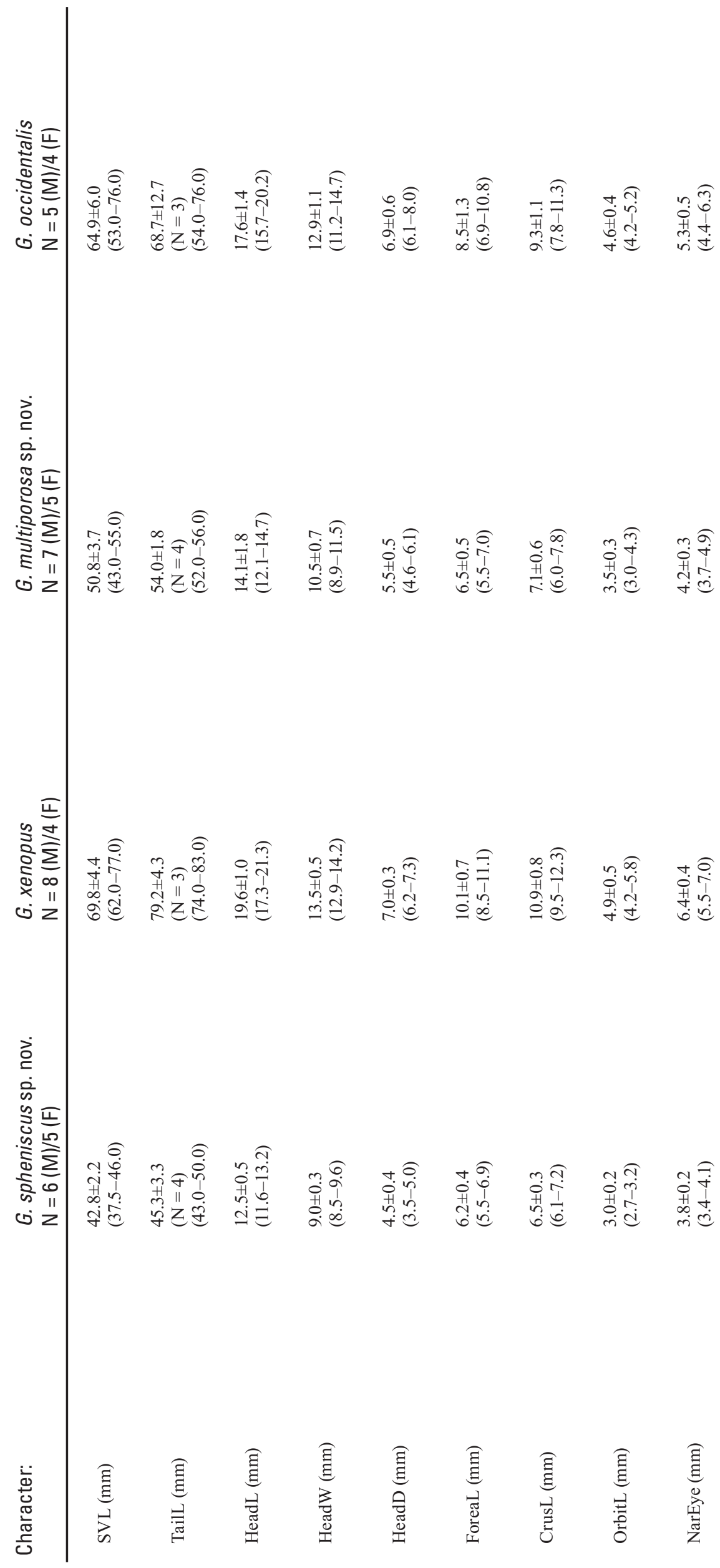




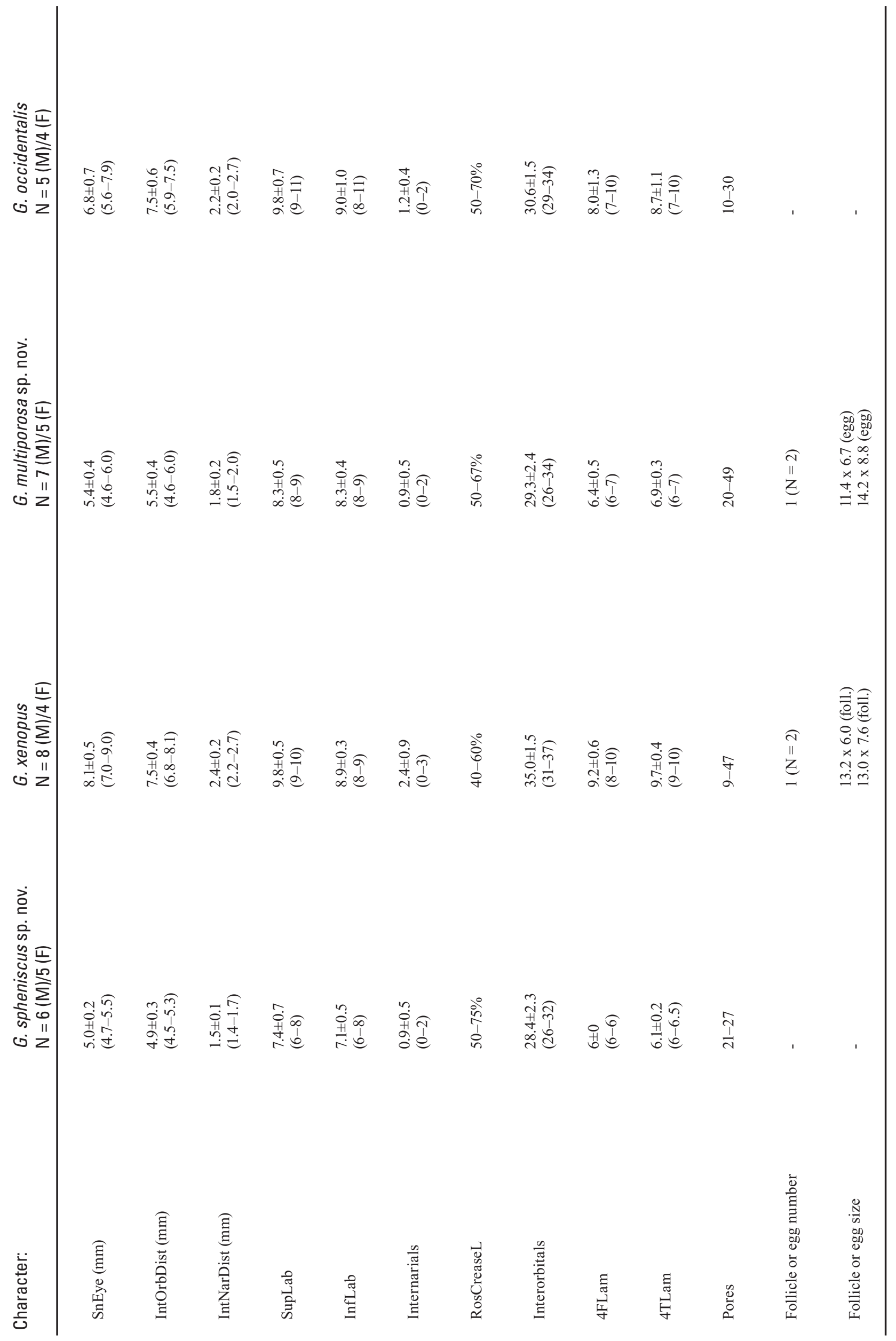


and examination of the type of G. xenopus (Figure 5) indicates the species is conspecific with the largerbodied lineage, and is corroborated by the sequence data from a specimen (WAM R172064) collected at the type location (King Edward River [14.8858 $\left.{ }^{\circ} \mathrm{S} ; 126.2033^{\circ} \mathrm{E}\right]$; location $\mathrm{x} 9$ in Figure 1) in the large-bodied lineage.

The two major lineages with the general characteristics of $G$. occidentalis differed in body size, dorsal pattern and other characters (Figure 6). In addition, there was a small-bodied population from Kingfisher Island (samples are labelled o5 in Figures 1 and 2) with moderate genetic divergence, and a large-bodied population from Mt Nyulasy in the east Kimberley (labelled o10) with very little genetic differentiation from typotypic G. occidentalis (see below). Samples from the Yampi Peninsula (o1-o4) were similar morphologically to typotypic G. occidentalis, yet differed somewhat genetically (Figure 2). Comparison of specimens from both lineages with the type of $G$. occidentalis (Figure 5) revealed that the larger, paler forms were conspecific with the type of $G$. occidentalis and the smaller, darker form represented a separate taxon. This is corroborated by the inclusion of sequence from four specimens (WAM R172070, R172089, R172092, R172106) of the larger, paler form genetic lineage from the holotype locality of G. occidentalis (Manning Gorge - location o9 in Figure 1).

\section{DISTRIBUTION}

Figure 1 shows the distribution of all four lineages treated here. The distributions of the two forms allied with G. xenopus largely overlap, with records from the Mitchell Plateau, Prince Regent River Nature Reserve and one near-shore island. Records from Galvans Gorge and the King Leopold Ranges extend the distribution of the small-bodied form south and inland. The distribution of typical G. xenopus extends further along the coast from Kalumburu in the north and south of the Walcott Inlet.

The darker, smaller form allied with G. occidentalis has a distribution centred on the north-western coast of the Kimberley, and only penetrates $\sim 100 \mathrm{~km}$ inland. In contrast, typical G. occidentalis is largely allopatric, occurring in the slightly drier south-west (Yampi) and southern Kimberley, and in an isolated population at Mt Nyulasy in the eastern Kimberley. The two populations may overlap in their distributions between Walcott Inlet and the southern parts of the Prince Regent River Nature Reserve (Figure 1).

Thus, although overlapping through parts of the north-west Kimberley, the distribution of taxa within each species pair group indicated different natural ranges, supporting the concept of more than two species being involved (regional sympatry) and suggestive of ecological preferences or physiological differences among them.

\section{TAXONOMIC CONCLUSIONS}

Based on the morphological, molecular genetic and
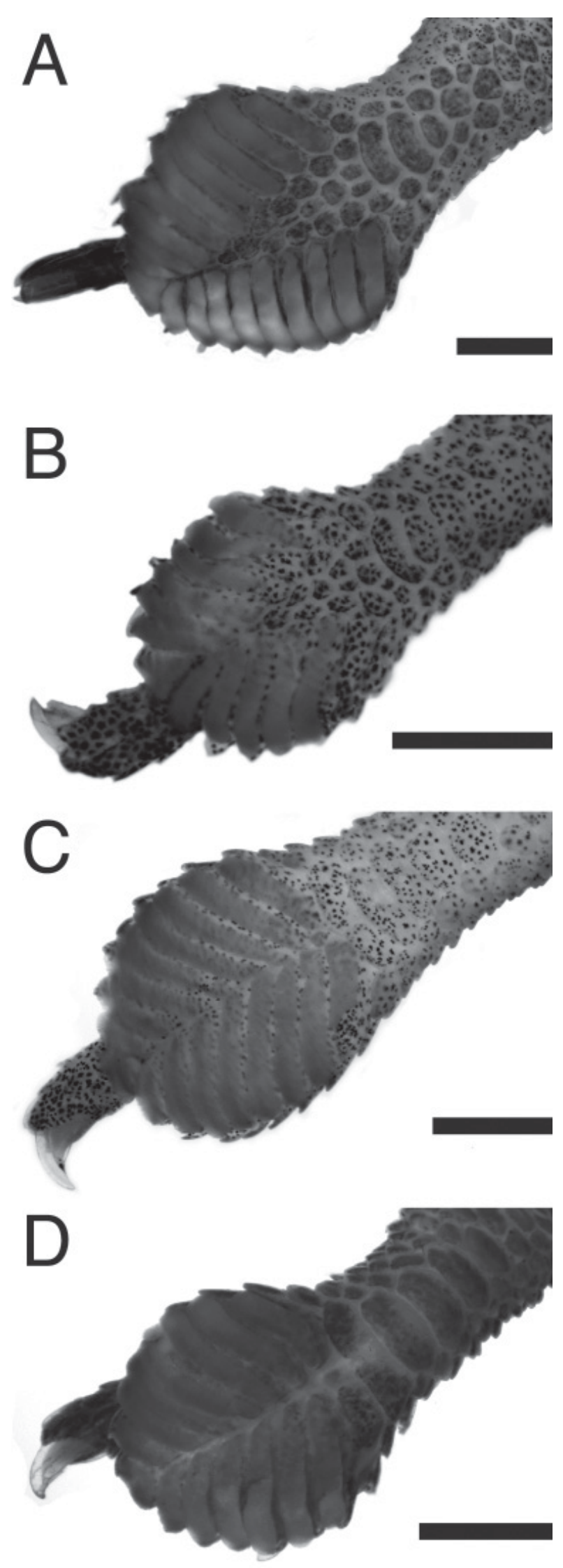

FIGURE 4 Close-up views of the fourth toe pads: A, Gehyra xenopus; B, G. spheniscus sp. nov.; C, G. occidentalis; D, G. multiporosa sp. nov. Scale bar $=1 \mathrm{~cm}$. 


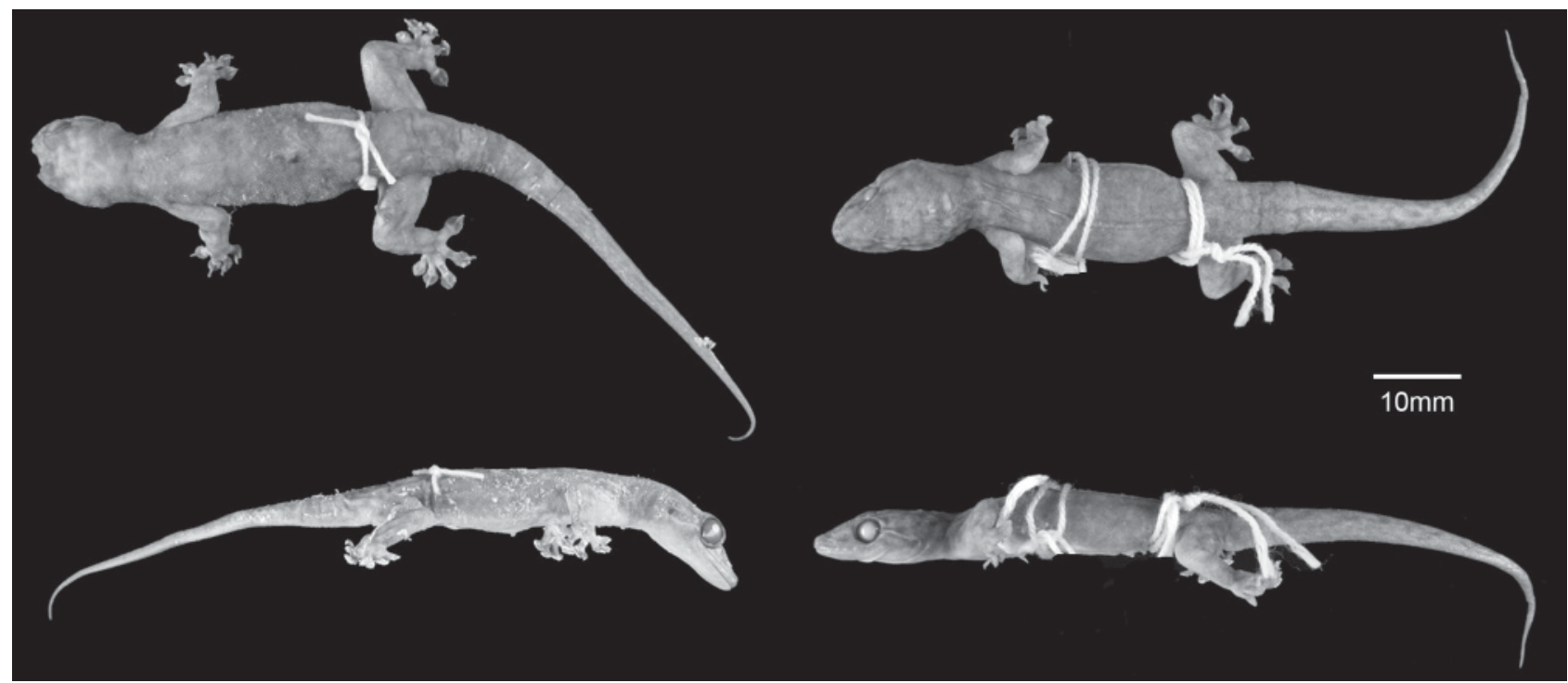

FIGURE 5 Holotypes of Gehyra xenopus (left; WAM R56429) and G. occidentalis (right; WAM R83711) in dorsal (upper) and lateral (lower) views.

distributional data, we conclude there is an additional species within each of the nominal species treated here. Accordingly, below we describe the small-bodied forms within each species pair as a new species.

We also comment here on body size variation in $G$. occidentalis. The occurrence of the isolated, largebodied (cf. Figure 6, right-most specimen) Gehyra from Mt Nyulasy in the eastern Kimberley was perplexing, as it was not referable to any known Gehyra based on current understanding of species morphological and distributional limits (Storr et al. 1990). However, the genetic analyses clearly indicated this population is genetically close to topotypic G. occidentalis (Figure 2). By contrast, specimens from a small-bodied population of $G$. occidentalis (identified from the genetic analysis) from the Kingfisher Island group were originally used as paratypes in the description of G. nana by Storr (1978) due to their usually small adult body size (mean SVL:
$54 \mathrm{~mm}, \mathrm{~N}=13$; RP, unpublished data) and similar dorsal pattern. Changes in body size were also accompanied by changes in subdigital lamellae counts, commonly used in Gehyra taxonomy, resulting in a wide range for this and other morphometric characters presented in Table 1 for $G$. occidentalis compared to the other three taxa treated here. The eastern and central Kimberley region is poorly sampled, other than the Kununurra area, Drysdale River National Park and along the sealed Great Northern Highway (the only extensively sealed road in the Kimberley that largely runs through savannah south of the region). Therefore it is possible that G. occidentalis occurs continuously from the south-west to the east Kimberley and that body size variation is clinal. Recent work on Gehyra from southern Australia, however, indicates that body size evolution can occur rapidly when populations are isolated, especially on remote outcrops (Sistrom et al. 2012). This is an interesting

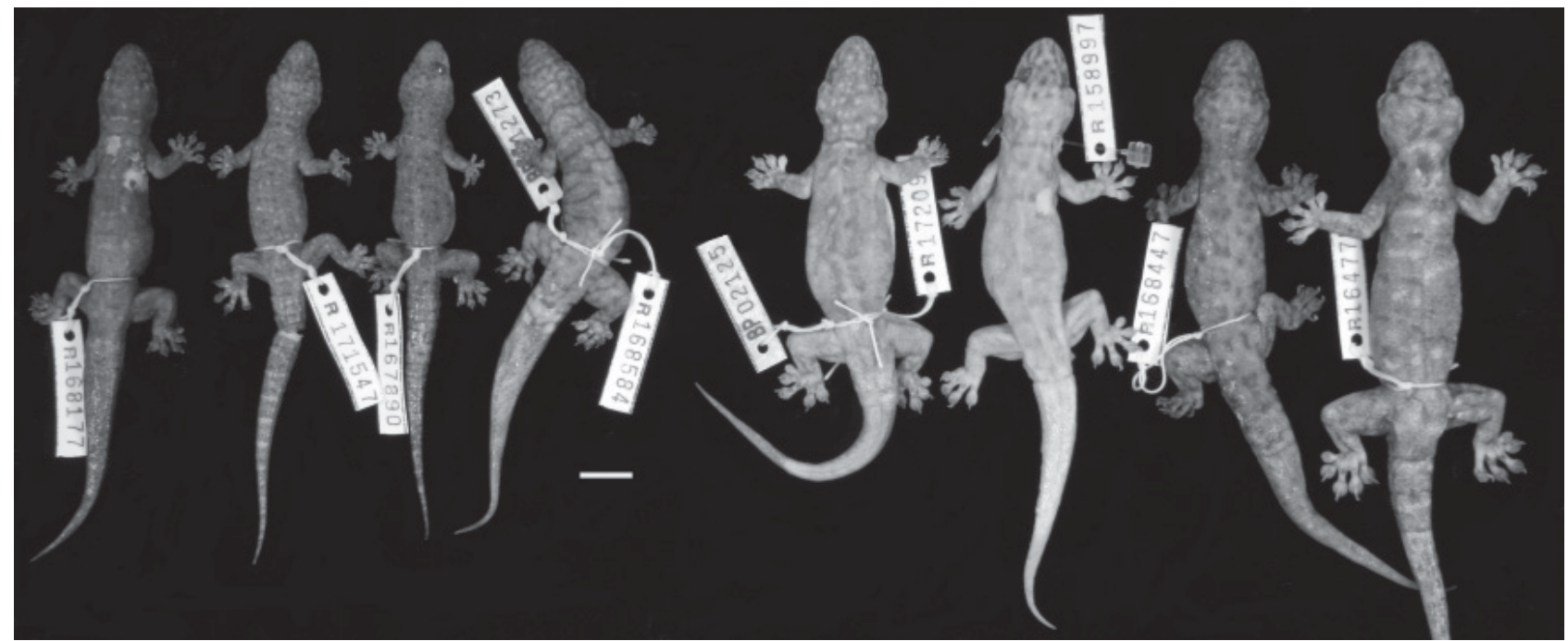

FIGURE 6 Variation between Gehyra multiporosa sp. nov. paratypes (left) and G. occidentalis (right). Scale bar $=1 \mathrm{~cm}$. 
area for future investigation and relevant to taxonomic investigations if body size is highly labile evolutionarily. Furthermore, although the Yampi Peninsula specimens of G. occidentalis were somewhat genetically divergent, they conformed largely in morphology to other G. occidentalis s.s. specimens and so we conservatively do not treat them separately here.

\section{TAXONOMY}

\section{Genus Gehyra Gray, 1834}

\section{TYPE SPECIES}

Gehyra pacifica Gray, 1834 (=Gehyra oceanica [Lesson, 1830]), by monotypy. Note that the date of description of Gecko oceanicus has sometimes been given as 1826 (e.g. Bauer and Henle 1994; Crombie and Pregill 1999), based on Ineich's (1987) assertion that the date of the plate depicting the type and presenting the name was published four years in advance of the corresponding text. However, a recent comprehensive dating of the parts of the zoology of the voyage of the Coquille (Cretella 2010) reveals that the relevant plate was actually also published in 1830 .

\section{Gehyra spheniscus sp. nov.}

urn:Isid:zoobank.org:pub:667C5E6A-3EE0-46F9-841ACFAF2D4ABCE3

Small Wedge-toed Gecko

Figures $3,4,7,9$

\section{MATERIAL EXAMINED}

\section{Holotype}

Australia: Western Australia: WAM R171591* (male), collected from Lower Monjon Rocks, Prince Regent River Nature Reserve $\left(15.9775^{\circ} \mathrm{S} ; 125.3678^{\circ} \mathrm{E}\right)$ on
25 January 2010 by C.A. Stevenson and R. Somaweera.

\section{Paratypes}

Australia: Western Australia: WAM R167810* (female), Surveyors Pool, Mitchell Plateau (14.6733 ${ }^{\circ}$; $125.7322^{\circ} \mathrm{E}$ ); WAM R168715* (female), Katers Island $\left(14.4666^{\circ} \mathrm{S} ; 125.5333^{\circ} \mathrm{E}\right)$; WAM R171402* and WAM R171460 (males), Prince Regent River Nature Reserve $\left(15.9897^{\circ} \mathrm{S} ; 125.3294^{\circ} \mathrm{E}\right)$; WAM R171434 (female) Prince Regent River Nature Reserve $\left(16.0000^{\circ} \mathrm{S} ; 125.3328^{\circ} \mathrm{E}\right)$; WAM R171570* (male), Old Beverley Springs Road, $25 \mathrm{~km}$ south of Prince Regent River Nature Reserve $\left(16.1763^{\circ} \mathrm{S} ; 125.4392^{\circ} \mathrm{E}\right)$.

\section{DIAGNOSIS}

Digits broadly expanded basally and subdigital scansors present on all digits of manus and pes. Digit I of manus and pes clawless or bearing a minute claw, penultimate phalanx of digits II-V free from scansorial pad. Body atuberculate. Differs from non-Australian Gehyra by lack of extensive webbing between toes III and IV and a cutaneous fold along the posterior margin of the hindlimb, and the presence of transversely widened subcaudal scales. Differs from Australian species by small ( $45 \mathrm{~mm}$ SVL) body size and a wedge of granules at the base of the expanded terminal pads on the digits; further distinguished from $G$. xenopus by 6 lamellae on fourth finger and toe, 7 or 8 upper and lower labials, single internarial, $\sim 30$ interorbital scales, $\sim 25$ precloacal and femoral pores in males in an unbroken chevron and dorsal pattern with transverse rows of alternating light and dark spots or bars.

\section{DESCRIPTION OF HOLOTYPE}

Body small (44.0 mm SVL), depressed, with welldefined ventro-lateral fold. Head depressed $(\mathrm{HeadH}=$ $35 \%$ HeadL), in profile snout moderately long (SnEye = $39 \%$ HeadL) and longer than eye (OrbL $=64 \%$ SnEye), snout (interorbital/frontal region) slightly convex, canthal region slightly raised, forming concavity in

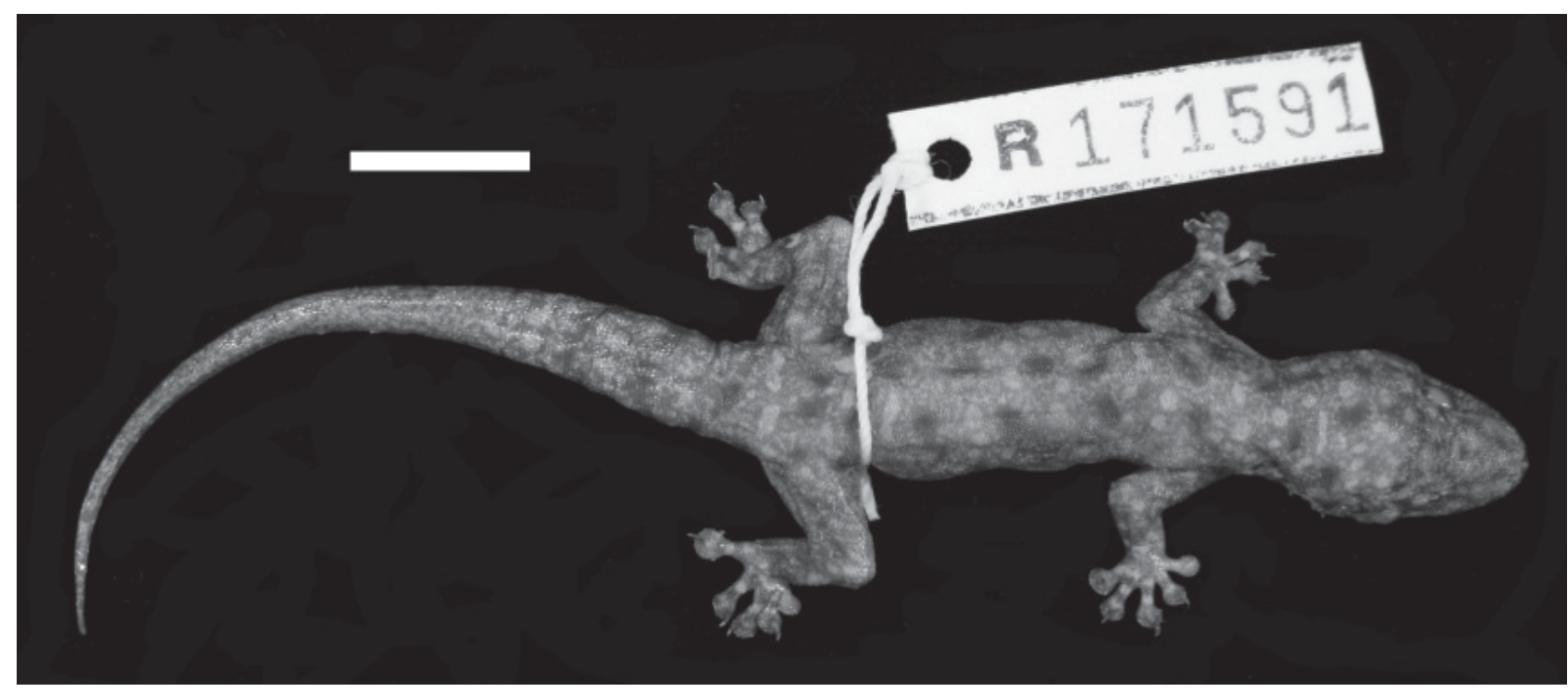

FIGURE 7 Holotype of Gehyra spheniscus sp. nov. (WAM R171591). Scale bar $=1 \mathrm{~cm}$. 
between, nostril slightly swollen; head widest behind eyes narrowing anteriorly to moderately wide and rounded snout; neck constricted to two-thirds maximum head width. Scales on top and sides of snout $>5$ times larger than on crown and rest of body; scales in contact with nostril - rostral, supranasal, 2 postnasals and first supralabial; supra- and infralabials 7; rostral width 2.2 $\mathrm{mm}$, height $1.4 \mathrm{~mm}$, strongly gabled dorsally, deeply furrowed medially, rostral crease $\sim 60 \%$ of height of rostral; internarial 1; nostrils circular and directed posterodorsally. Mental length $2.5 \mathrm{~mm}$, triangular, penetrating to $\sim$ middle of inner chin shields; inner chin shields in contact with first infralabial; outer chin shield less than half height of inner chin shield with rounded outer edge, in contact with second infralabial; eye small $(\mathrm{OrbL}=25 \%$ HeadL), pupil oval with crenulated edges; above eye a projecting anterior ridge and posteriorventral edge slightly covered by loose skin; ear opening small and circular; 32 interorbital scales between furrows above eyes.

Dorsal scales small and homogeneous, juxtaposed, moderately rounded with apex slightly posterior; ventral scales 2-4 times larger than dorsal scales, flat and slightly imbricate; approximately 115 mid-body scale rows; scales on limbs as for body. Precloacal and femoral pores 24, arranged in a continuous curved chevron with the apex pointing anteriorly; cloacal spurs 4 enlarged, rounded and projecting scales on both sides of cloacal opening.

Limbs short (ForeaL $=14 \%$ SVL; CrusL $=15 \%$ SVL), moderately developed; projecting narrow claws present on all digits except digit I, claw projects above and beyond expanded toe pads, dorsal border of toe pad with elongate row of scales forming a fringe; below digit a single row of enlarged round to oval tubercles; no webbing between digits; subdigital lamellae divided, number on fourth finger and toe 6 , up to 10 small granules forming a narrow triangle at the base of the toe pad and separating four proximal lamellae; distal two rows of lamellae in contact (Figure 4). Tail long and thin, ovoid in cross-section proximally, tapering to a fine point; proximal $14 \mathrm{~mm}$ of tail original, distal $36 \mathrm{~mm}$ regenerated; scales on dorsal surface of tail $\sim 2 \mathrm{x}$ size of scales on body dorsum, arranged in regular rows; ventral scales of original tail enlarged ( $2.5 \times 1.1 \mathrm{~mm}$ at base) and oriented transversely, scales on regenerated portion as for original but forming less regular rows.

\section{Colouration}

In preservative, base colour of dorsum light brown; a total of approximately 14 irregular rows of alternating pale and dark brown spots or bars from neck to hindlimbs; pale markings with thin dark edge, tending to form bars on neck and near hindlimbs, dark brown markings 1.5-2 times larger than pale markings and with less well-defined edges; head as for body but spots smaller and denser, no conspicuous dark streaks posterior to left eye (skin damaged on right side); supralabials and rostral dark brown; dorsal surface of limbs with diffuse markings; ventrum pale with diffuse pigmentation, infralabials and ventral surface of tail slightly darker, palmar and plantar surfaces darkly pigmented. In life, as for preserved specimen, but light reddish hue to background colour, markings more welldefined and eye orange with dark pupil.

\section{VARIATION}

Table 1 presents variation in meristic characters, and Figure 3 shows the range of variation of dorsal patterns. Most individuals corresponded well with the holotype except as noted below. Females lack pores and cloacal spurs. Colouration in life varied from a brown background colour to a light red to salmon hue; a thin pale vertebral stripe was often present. Alternating rows of pale and dark markings were present on all specimens, but some tended to join to form transverse bars whereas in other specimens there were rows of discrete spots (Figure 3). If present, the transverse bars were interrupted by the pale vertebral zone.

\section{HABITAT}

All specimens were collected from areas of rugged sandstone. Collection notes mention the tops of open sandstone platforms, the top of a large boulder on a high outcrop and one specimen from a tree in a wetland adjacent to a low rocky ridge.

\section{DISTRIBUTION}

Confined to the north-west Kimberley region, most specimen records occur from the Prince Regent River Nature Reserve and the Mitchell Plateau. Also on Katers Island adjacent to Mitchell Plateau. There is one record near Charnley River Station and a single, older record from Galvans Gorge in the Phillips Range, extending the distribution southwards and inland (Figure 1).

\section{ETYMOLOGY}

The epithet spheniscus (Latinized Greek), meaning 'a small wedge' refers to the triangle-shaped wedge of granules on the toe pads. Used as a noun in apposition.

\section{COMPARISON WITH OTHER SPECIES}

Superficially, spotted G. spheniscus individuals resemble those of $G$. nana owing to the latter's similar small body size ( 40-50 mm SVL), and they co-occur in the same rugged sandstone country of the north-west Kimberley. The possession of the triangular patch of granules at the base of the digits, however, easily distinguishes $G$. spheniscus sp. nov. from $G$. nana. In addition, G. nana occurs more among boulders and low-lying rocks rather than on vertical rock surfaces (RP, pers. obs.). Among species of Gehyra, possession of a triangular wedge of granules at the base of the toe pad distinguishes G. spheniscus and $G$. xenopus from all other species, and these two species are distinguished by many morphological features (see Table 1 and diagnosis, above). 


\section{Gehyra multiporosa sp. nov.}

urn:Isid:zoobank.org:pub:667C5E6A-3EE0-46F9-841ACFAF2D4ABCE3

Multi-pored Gecko

Figures 4, 6, 8, 10

\section{MATERIAL EXAMINED}

\section{Holotype}

Australia: Western Australia: WAM R167804* (male), Surveyors Pool, Mitchell Plateau $\left(14.6733^{\circ} \mathrm{S}\right.$; $125.7322^{\circ} \mathrm{E}$ ) on 9 January 2007 by P. Doughty and C.A. Stevenson.

\section{Paratypes}

Australia: Western Australia: WAM R167890* (male), Mitchell Plateau $\left(14.8292^{\circ} \mathrm{S} ; 125.7211^{\circ} \mathrm{E}\right)$; WAM R168177* (female), Boongaree Island $\left(15.0763^{\circ} \mathrm{S}\right.$; $\left.125.1836^{\circ} \mathrm{E}\right)$; WAM R168577* (male), Augustus Island $\left(15.3500^{\circ} \mathrm{S} ; 124.5333^{\circ} \mathrm{E}\right)$; WAM R168584* (female), Byam Martin Island $\left(15.3833^{\circ} \mathrm{S} ; 124.3500^{\circ} \mathrm{E}\right)$; WAM R171491* (male), Prince Regent River Nature Reserve (15.2947 ${ }^{\circ}$; $\left.125.4950^{\circ} \mathrm{E}\right)$; WAM R171547* (male), Prince Regent River Nature Reserve $\left(15.7616^{\circ} \mathrm{S} ; 125.2561^{\circ} \mathrm{E}\right)$.

\section{DIAGNOSIS}

Digits broadly expanded basally and subdigital scansors present on all digits of manus and pes. Digit I of manus and pes clawless or bearing a minute claw, penultimate phalanx of digits II-V free from scansorial pad. Body atuberculate. Differs from other Australian Gehyra by lacking strong skin fold on posterior edge of thigh, possessing 6 or 7 divided lamellae (without basal wedge of granules), enlarged inner chin shields not in contact with second infralabial, strongly gabled rostral, $>40$ precloacal and femoral pores in adult males and a dorsal pattern with pale spots and dark spots, or transverse bars, on a dark brown background. Further distinguished from G. occidentalis by smaller body size, darker dorsum and pattern with transverse bars and fewer well-defined spots, fewer subdigital lamellae and more numerous precloacal and femoral pores.

\section{DESCRIPTION OF HOLOTYPE}

Body size moderately small $(50.0 \mathrm{~mm}$ SVL) with robust habitus, depressed dorsally, flat ventrally with defined ventro-lateral fold. Head moderately depressed $($ HeadD $=45 \%$ HeadL), in profile snout moderately long $($ SnEye $=40 \%$ HeadL $)$ and longer than eye $(\mathrm{OrbL}=66 \%$ SnEye), snout (interorbital/frontal region) almost straight (a slight convexity), canthus rounded and slightly raised forming shallow concavity in between, nostril region only slightly swollen; in dorsal view head widest behind eyes narrowing anteriorly to broadly rounded snout; neck constricted to $3 / 4$ maximum head width. Scales on top and sides of snout $>5$ times larger than crown and rest of body; scales in contact with nostril - rostral, supranasal, 2 postnasals and first supralabial; supra- and infralabials 8; rostral width $2.0 \mathrm{~mm}$, height $1.1 \mathrm{~mm}$, strongly gabled dorsally, deeply furrowed medially, rostral crease $\sim 60 \%$ of height of rostral; surfaces of labial and rostral scales dimpled; internarial 1; nostrils circular and directed posterodorsally. Mental $2.3 \mathrm{~mm}$ long, 1.9 $\mathrm{mm}$ wide, triangular, not penetrating to middle of inner chin shields; elongate inner chin shields not in contact with first infralabial (excluded by outer chin shields); outer chin shield $\sim 60 \%$ of height of inner chin shield with rounded outer edge, in short contact with first infralabial and broad contact with second infralabial; eye small $(\mathrm{OrbL}=27 \%$ HeadL), pupil oval with crenulated edges (3 scallops on each side); above eye a projecting anterior ridge and posterior-ventral edge slightly covered by loose

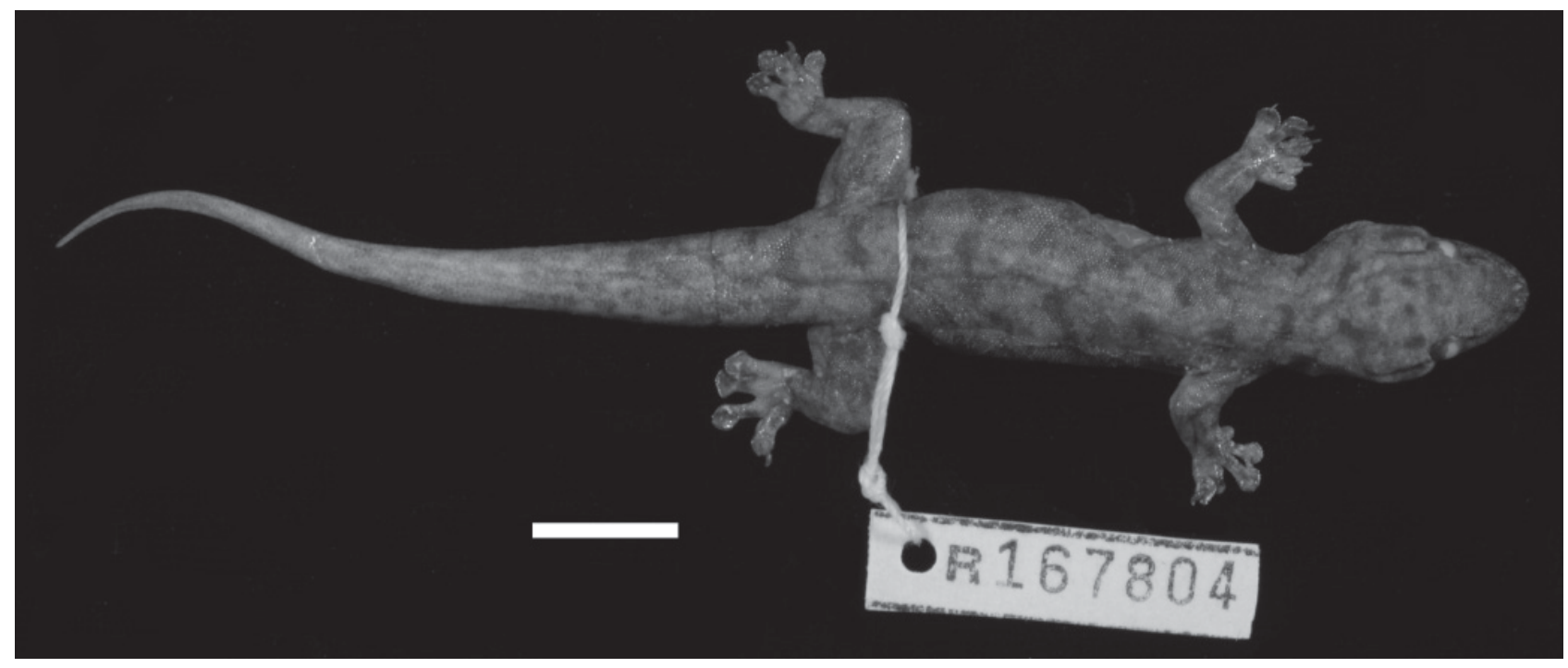

FIGURE 8 Holotype of Gehyra multiporosa sp. nov. (WAM R167804). Scale bar $=1 \mathrm{~cm}$. 


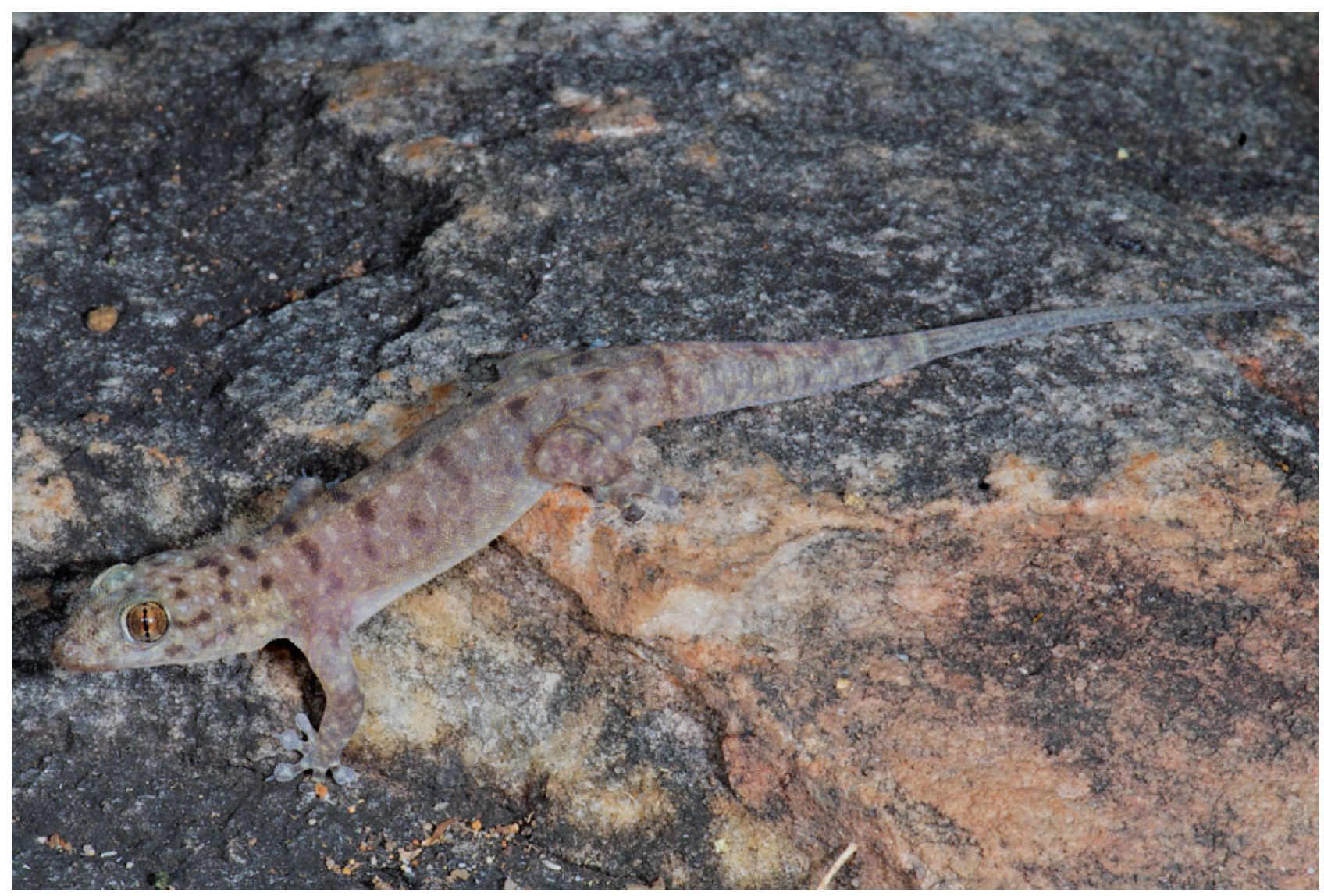

FIGURE 9 Photo of Gehyra spheniscus sp. nov. in life from Mitchell Plateau, Western Australia (uncollected individual) (image: S. MacDonald).

skin; ear opening small and circular; 31 interorbital scales between furrows above eyes.

Dorsal scales small and homogeneous, juxtaposed, moderately rounded with apex slightly posterior; ventral scales $\sim 2$ times larger than dorsal scales, flat and slightly imbricate; approximately 128 mid-body scale rows; scales on limbs as for body. Precloacal and femoral pores 48 , arranged in a continuous curved line, chevron-shaped medially with the apex pointing anteriorly, distally continuing along posterior edge of thigh almost to knee in a straight line; cloacal spurs 3 slightly enlarged, rounded and projecting scales on both sides of cloacal opening.

Limbs short (ForeaL $=13 \%$ SVL; CrusL $=14 \%$ SVL), moderately developed, especially rear limbs; projecting narrow claws present on all digits except digit I (missing on right manus), claw projects above and beyond expanded toe pads, dorsal edge of toe pad with elongate row of scales forming a fringe; below digit a single row of enlarged round to oval tubercles increasing in size towards toe pads; no conspicuous webbing between digits; subdigital lamellae divided, number on fourth finger and toe 7 (Figure 4). Tail long and thin, ovoid at body, tapering to a fine point; proximal original tail $7 \mathrm{~mm}$ from cloaca, distal regenerated portion $46 \mathrm{~mm}$;

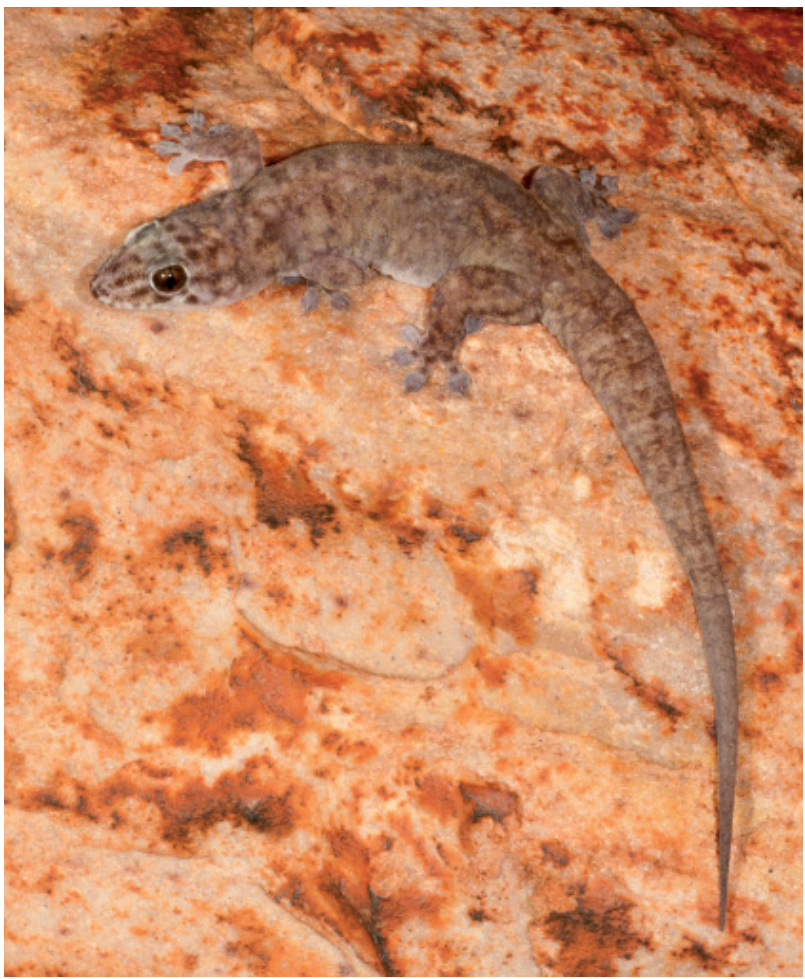

FIGURE 10 Photograph of Gehyra multiporosa sp. nov. from Doongan Station, Western Australia (uncollected individual) (image: H. Cook). 
scales on dorsal surface of original tail $\sim 2 \mathrm{x}$ size of scales on body, flattened and arranged in neat concentric rows; ventral scales of original tails enlarged $(2.5 \times 1.5 \mathrm{~mm}$ at base) and oriented transversely, scales on regenerated portion as for original but forming less ordered rows.

\section{Colouration}

In preservative, dark brown background colour on dorsum; a total of approximately 9 rows of dark brown bars (posteriorly) or spots (anteriorly) on dorsum (from neck to hindlimbs), interspersed with diffuse pale markings or spots; head as for body but dark spots smaller and denser, a conspicuous dark streak posterior to middle of eye, shorter and thinner streaks behind upper edge of eye; supralabials, rostral and lower sides of snout dark brown; dorsal surface of limbs with diffuse markings; ventrum pale with diffuse pigmentation, infralabials and ventral surface of tail slightly darker, palmar and plantar surfaces darkly pigmented. In life, as for preserved specimen, but light reddish hue to background colour and pale markings more defined, especially on head; eye orange with dark pupil.

\section{VARIATION}

Table 1 shows variation in meristic characters, and most individuals corresponded well with the holotype except as noted below. Females lacked pores and the cloacal spurs of males. Males over $50 \mathrm{~mm}$ SVL all had $>40$ pores, whereas two males with SVLs of 46 and 47 $\mathrm{mm}$ had 20 and 22 pores, respectively. Colouration in life varied from a dark greyish-brown background colour to a light red to salmon hue. Dark markings usually formed transverse bars and were larger than pale markings; pale markings were often spots but could also form bars; alternating rows of the dark and pale markings was strong in some specimens compared to the less ordered pattern in the holotype. Other specimens had a vertebral zone or thinner stripe of lighter pigment that interrupted any transverse markings, and some specimens had a dark line along the canthus.

\section{HABITAT AND ECOLOGY}

Specimens have been encountered largely on rock faces around sandstone platforms and boulders and also from basalt (volcanic) rocks. Collection notes also indicate specimens being found in rainforest gullies and around rocky creeks, possibly indicating a preference for moist microhabitats. Individuals were also observed perched on trunks or branches of dead trees (usually Acacia with rough bark) along rocky sandstone creeks that lacked extensive rock faces. Shea et al. (1988) noted a 'G. occidentalis' on a tree in open woodland over laterite on the Mitchell Plateau. They also reported observing a group of geckos around oozing sap high in a eucalypt tree that were potentially this species. On a number of occasions, G. multiporosa sp. nov. was also trapped in funnel traps set in rocky sandstone habitat with spinifex during the Kimberley Islands survey (RP, unpublished data). On surveyed islands in the Kimberley, $G$. multiporosa sp. nov. and its sister species G. occidentalis are allopatric, but they do co-occur with G. nana, $G$. xenopus and G. spheniscus sp. nov. on islands.

\section{DISTRIBUTION}

This species is confined to the north-west Kimberley region, generally within $100 \mathrm{~km}$ of the coastline from the Mitchell Plateau to Walcott Inlet. Also occurs on many offshore islands from Cape Voltaire to Doubtful Bay, including most of the larger ( $>500 \mathrm{ha}$ ) islands in the Bonaparte Archipelago from Katers Island in the north through to Byam Martin Island in Camden Sound, and further south to Storr Island and an un-named island in the Doubtful Bay area.

\section{ETYMOLOGY}

Derived from multi (Latin) meaning 'many' and porus (Latinized from the Greek poros) meaning hole, in reference to the precloacal pores; thus, 'many-pored' in reference to the diagnostic character compared to its sister species G. occidentalis. Used as an adjective.

\section{COMPARISON WITH OTHER SPECIES}

Compared to other Gehyra from the Kimberley, $G$. multiporosa has a moderate body size and somewhat obscure dorsal pattern that overlaps with that of many other species from the region. This is evidenced by the inclusion of six specimens of $G$. multiporosa sp. nov. as $G$. nana paratypes and one as a paratype of $G$. occidentalis. Possession of divided lamellae without a wedge of granules distinguishes it from $G$. australis and G. koira (undivided lamellae) and G. xenopus and G. spheniscus (wedge of granules). Gehyra nana is smaller and possesses scattered spots. Gehyra pilbara from the southern Kimberley have a much shorter snout, a flat-topped rostral scale, and narrower and shorter chin shields. These taxa are not known to occur sympatrically but they may overlap in the poorly surveyed Harding Range north of Walcott Inlet.

Gehyra multiporosa sp. nov. is most similar to its sister species, G. occidentalis, but differs by having a darker background colouration with less defined markings, dimpled labial and rostral scales and fewer labial scales and subdigital lamellae. As these sister taxa are ecologically similar, they appear to be allopatric on islands (RP, unpublished data) and the mainland, although they may overlap in their distributions in the Harding, Edkins and possibly the Caroline Ranges between Walcott Inlet and the southern parts of the Prince Regent Nature Reserve (Figure 1). In general terms, G. multiporosa sp. nov. occupies the wetter $(>1000 \mathrm{~mm})$ part of the north-west Kimberley and $G$. occidentalis the slightly drier southern, south-west 
(Yampi) and central parts of the Kimberley plateau.

\section{DISCUSSION}

The combination of the confused taxonomy of Gehyra plus the lack of knowledge of the Kimberley fauna has made revision of Kimberley Gehyra difficult. Although several specimens of each taxon were collected in the 1970s and 1980s, both species descriptions were reliant on new material (vouchers and associated tissue samples) collected only in the past five years through recent WAM and DEC surveys (e.g. Doughty 2011; Gibson and McKenzie 2012). In addition, the application of molecular genetic techniques to problems within Gehyra has resulted in another strong line of evidence to begin to search for characters that can discriminate between species-level genetic divergences (see also Sistrom et al. 2009). In the case of G. spheniscus sp. nov., morphology and genetics both played a significant role, as this species is morphologically distinct and not closely related to G. xenopus. For G. occidentalis and G. multiporosa sp. nov., the genetic data was essential as the appearance of these species overlaps with several other taxa. In addition, the problem with Gehyra of patterns and colouration being lost in preservative in older specimens leads to many misidentifications. Molecular genetics also resolved the affinities of the population of G. occidentalis on Kingfisher Island with small body size (with some older specimens nominated by Storr [1978] as paratypes of G. nana) and the largebodied population from Mt Nyulasy in the eastern Kimberley which was closely related to $G$. occidentalis s.s. The variation in body size among G. occidentalis populations in the Kimberley may mirror the pattern seen in body size evolution in Gehyra from South Australia (Sistrom et al. 2012) where large differences in body size exist among populations with few genetic differences among them (see also Doughty et al. 2008 for an example with Diplodactylus granariensis).

The description of two species of Gehyra brings the number of described lizard species from the northern Kimberley region to 89 , including 25 endemic species. Although the Kimberley region is recognised as a centre of endemism within the Australian landscape (Cracraft 1991; Slatyer et al. 2007; Bowman et al. 2010), there are still significant questions regarding the true number of species from the region and the limits of species boundaries. Distinctive new species of plants, snails and frogs are still being discovered at high rates, despite the region being subjected to sporadic surveys since the 1970s (Shea and Johnston 1987; Smith and Johnstone 1991; Solem and McKenzie 1991; Barrett 2006; Doughty 2011; Köhler 2011; Bauer and Doughty 2012). In addition, new collections of plants and animals have resulted in larger series that have enabled workers to detect consistent differences among new candidate taxa within what were believed to be variable species (e.g. Horner 2005; Oliver et al. 2010b; Pepper et al. 2011; this study). For these reasons, current estimates of species diversity are likely to be much lower than the true species diversity, a consideration that should factor in any decisions regarding conservation planning.

Rocky regions can provide several key features that may lead to elevated speciation rates and or lower extinction rates. First, topographical relief provides a more complex environment than flatter savannahs or sandy deserts. For example, animals adapted for climbing trees can shift to a vertical rock surface (e.g. Litoria frogs, Oedura geckos, small-bodied Varanus lizards). Second, rocky areas provide moist microhabitats by possessing a complex structure that maintains a humid microhabitat for organisms that can persist through periods of harsher environmental conditions (Couper and Hoskin 2009; Bowman et al. 2010; Pepper et al. 2011). Third, rocky areas surrounded by different habitats may result in speciation if long distance colonisation to a different rocky area occurs (Oliver et al. 2010b; Doughty et al. 2011; Pepper et al. 2011). In the case of the Gehyra presented here, it seems likely that the north-west Kimberley has provided moist refugia with a complex topography where in situ speciation has occurred.

\section{ACKNOWLEDGEMENTS}

For funding of fieldwork we thank Alcoa of Australia, DEC, the Australian Biological Resources Study (grant number 207-43) and W.H. and M. Butler. The Kimberley Islands survey was possible through a research agreement with the Kimberley Land Council for the Balanggarra, Bardi-Jawi, Wanjina-Wunggurr Dambimangari, Mayala and Wanjina-Wunggurr Uunguu native title groups, with funding provided by the Natural Heritage Trust and DEC. We thank our field colleagues during Kimberley Gehyra collection, especially C. Stevenson, M. and R. Barrett, P. Kendrick, D. Pearson, L. Gibson, V. Kessner, R. Teale, M. Cowan, N. McKenzie, R. Somaweera, M. Pepper, G. Sparkes, B. Maher and T. Anders. We thank J. Daza and V. Reynen for assistance with images in the lab, S. MacDonald and H. Cook for use of live photographs and K. Armstrong and S. Potter for some of the DNA sequencing. A residency at Villanova University by PD was made possible by a fellowship from the Winston Churchill Trust, with assistance from C. Stevenson and T. Parkin for specimen loans. AMB was supported by grant DEB 0844523 from the National Science Foundation (U.S.A.).

\section{REFERENCES}

Barrett, R.L. (2006). A review of Planchonia (Lecythidaceae) in Australia. Australian Systematic Botany 19: 147-153.

Bauer, A.M. and Doughty, P. (2012). A new bent-toed gecko (Squamata: Gekkonidae: Cyrtodactylus) from the Kimberley region, Western Australia. Zootaxa 3187: 32-42. 
Bauer, A.M. and Henle, K. (1994). Das Tierreich 109. Gekkonidae. Part 1, Australia and Oceania. Walter De Gruyter Publishers: Berlin.

Bowman, D.M.J.S., Brown, G.K., Braby, M.F., Brown, J.R., Cook, L.G., Crisp, M.D., Ford, F., Haberle, S., Hughes, J., Isagi, Y., Joseph, L., McBride, J., Nelson, G. and Ladiges, P.Y. (2010). Biogeography of the Australian monsoon tropics. Journal of Biogeography 37: 201-216.

Cogger, H.G. (2000). Reptiles and amphibians of Australia. Sixth edition. Reed New Holland: Sydney.

Couper, P.J. and Hoskin, C.J. (2008). Litho-refugia: the importance of rock landscapes for the long-term persistence of Australian rainforest fauna. Australian Zoologist 34: 554-560.

Cracraft, J. (1991). Patterns of diversification within continental biotas: hierarchical congruence among the areas of endemism in Australian vertebrates. Australian Systematic Biology 4: 211-227.

Cretella, M. (2010). The complete collation and dating of the section Zoologie of the Coquille voyage. Bolletino Malacologico 46: 83-103.

Crombie, R.I. and Pregill, G.K. (1999). A checklist of the herpetofauna of the Palau Islands (Republic of Belau), Oceania. Herpetological Monographs 13: 29-80.

Doughty, P. (2011). An emerging frog diversity hotspot in the northwest Kimberley of Western Australia: another new frog species from the high rainfall zone. Records of the Western Australian Museum 26: 209-216.

Doughty, P., Oliver, P. and Adams, M. (2008). Systematics of stone geckos in the genus Diplodactylus (Reptilia: Diplodactylidae) from northwestern Australia, with a description of a new species from the Northwest Cape, Western Australia. Records of the Western Australian Museum 24: 247-265.

Doughty, P., Rolfe, J.K., Burbidge, A.H., Pearson, D.J. and Kendrick, P.G. (2011). Herpetologial assemblages of the Pilbara biogeographic region, Western Australia: ecological associations, biogeographic patterns and conservations. Records of the Western Australian Museum, Supplement 78: $315-341$.

Drummond, A. J., Ashton, B., Cheung, M., Heled, J., Kearse, M., Moir, R., Stones-Havas, S., Thierer, T. and Wilson, A. (2008). Geneious v4.0, available from http://www.geneious. $\mathrm{com} /$

Gibson, L.A. and McKenzie, N.L. (2012). Identification of biodiversity assets of selected Kimberley islands: background and implementation. Records of the Western Australian Museum, Supplement 81: 1-14.

Greer, A.E. (1989). The biology and evolution of Australian lizards. Surrey Beatty and Sons: Sydney.

Heinicke, M.P., Greenbaum, E., Jackman, T.R. and Bauer, A.M. (2011). Phylogeny of a trans-Wallacean radiation (Squamata, Gekkonidae, Gehyra) supports a single early colonization of Australia. Zoologica Scripta 40: 584-602.

Horner, P. (2005). Gehyra koira sp. nov. (Reptilia: Gekkonidae), a new species of lizard with two allopatric subspecies from the Ord-Victoria region of north-western Australia and a key to the Gehyra australis species complex. The Beagle 21: $165-174$.

Ineich, I. (1987). Recherches sur le peuplement et l'évolution des reptiles terrestres de Polynésie français. Ph.D. dissertation, Université des Sciences et Techniques du Languedoc: Montpellier, France.

King, M. (1982). Karyotypic evolution in Gehyra (Gekkonidae: Reptilia). II. A new species from the Alligator Rivers region in northern Australia. Australian Journal of Zoology 30: 93-101.

King, M. (1983a). The Gehyra australis species complex (Sauria: Gekkonidae). Amphibia-Reptilia 4: 147-169.

King, M. (1983b). Karyotypic evolution in Gehyra (Gekkonidae: Reptilia). III. The Gehyra australis complex. Australian Journal of Zoology 31: 723-741.

King, M. (1984a). A new species of Gehyra (Reptilia: Gekkonidae) from northern Western Australia. Transactions of the Royal Society of South Australia 108: 113-117.

King, M. (1984b). Three new species of Oedura (Reptilia: Gekkonidae) from the Mitchell Plateau of North Western Australia. Amphibia-Reptilia 5: 329-337.

Köhler, F. (2011). The camaenid species of the Kimberley Islands, Western Australia (Stylommatophora: Helicoidea). Malacologia 54: 203-406.

Mitchell, F.J. (1965). Australian geckos assigned to the genus Gehyra Gray (Reptilia, Gekkonidae). Senckenbergiana Biologica 46: 287-319.

Mortiz, C. (1986). The population biology of Gehyra (Gekkonidae): chromosome change and speciation. Systematic Zoology 35: 46-67.

Nei, M. (1987). Molecular evolutionary genetics. Columbia University Press: New York.

Oliver, P., Adams, M.A. and Doughty, P. (2010a). Molecular evidence for ten species and Oligo-Miocene vicariance within a nominal Australian gecko species (Crenadactylus ocellatus, Diplodactylidae). BMC Evolutionary Biology 10: 386 (11 pp.).

Oliver, P., Sistrom, M.J., Tjaturadi, B., Krey, K. and Richards, S. (2010b). On the status and relationships of the gecko species Gehyra barea Kopstein 1926, with description of new specimens and a range extension. Zootaxa 2354: 45-55.

Pepper, M., Fujita, M.K., Moritz, C. and Keogh, J.S. (2011). Palaeoclimate change drove diversification among isolated mountain refugia in the Australian arid zone. Molecular Ecology 20: 1529-1545.

Posada, D. and Crandall, K.A. (1998). Modeltest: testing the model of DNA substitution. Bioinformatics 14: 817-818.

Powney, G.D., Grenyer, R., Orme, C.D.L., Owens, I.P.F. and Meiri, S. (2010). Hot, dry and different: Australian lizard richness is unlike that of mammals, amphibians and birds. Global Ecology and Biogeography 19: 386-396.

Rambaut, A. and Drummond, A.J. (2007). Tracer v1.4. Available from http://beast.bio.ed.ac.uk/Tracer.

Ronquist, F. and Huelsenbeck, J.P. (2003). MrBayes 3: Bayesian phylogenetic inference under mixed models. Bioinformatics 19: $1572-1574$.

Shea, G.M. and Johnston, G.R. (1987). A new species of Notaden (Anura: Leptodactylidae) from the Kimberley Division of Western Australia. Transactions of the Royal Society of South Australia 112: 29-37.

Shea, G.M., Weigel, J., Harwood, A., Floriani, H. and Hemsley, C. (1988). Notes on the herpetofauna of Mitchell Plateau, Western Australia. Results of the 1987 Australian 
Herpetological Society field trip to the Kimberleys. Herpetofauna 18: 9-20.

Sistrom, M.J., Hutchinson, M.N., Hutchinson, R.G. and Donnellan, S.C. (2009). Molecular phylogeny of Australian Gehyra (Squamata: Gekkonidae) and taxonomic revision of Gehyra variegata in south-eastern Australia. Zootaxa 2277: 14-32.

Sistrom, M., Edwards D.L., Donnellan, S. and Hutchinson, M. (2012). Morphological differentiation correlates with ecological but not with genetic divergence in a Gehyra gecko. Journal of Evolutionary Biology 25: 647-660.

Slatyer, C., Rosauer, D. and Lemckert, F. (2007). An assessment of endemism and species richness patterns in the Australian Anura. Journal of Biogeography 34: 583-596.

Solem, A. and McKenzie, N.L. (1991). The composition of land snail assemblages in Kimberley rainforests (pp. 224-263). In: McKenzie, N.L., Johnston, R.B. and Kendrick, P.G. (eds), Kimberley rainforests of Australia. Surrey Beatty and Sons: Chipping Norton, Australia.

Stamatakis, A. (2006) RAxML-VI-HPC: Maximum likelihoodbased phylogenetic analyses with thousands of taxa and mixed models. Bioinformatics 22: 2688-2690.

Stamatakis, A., Hoover, P. and Rougemont, J. (2008). A rapid bootstrap algorithm for the RAxML web-servers. Systematic Biology 75: 758-771.

Storr, G.M. (1978). Seven new gekkonid lizards from Western Australia. Records of the Western Australian Museum 6: 337-352.

Storr, G.M., Smith, L.A. and Johnstone, R.E. (1990). Lizards of Western Australia. III. Geckos and pygopods. Western Australian Museum Press: Perth.

MANUSCRIPT RECEIVED 10 FEBRUARY 2012; ACCEPTED 31 AUGUST 2012. 
APPENDIX 1 Additional material examined. All specimens from WAM (prefixes excluded) and from Western Australia. Specimens that were also genotyped are indicated by an asterisk.

\section{Gehyra xenopus}

R127324* (female) - Walcott Inlet $\left(16.4502^{\circ} \mathrm{S}\right.$; $124.7667^{\circ} \mathrm{E}$ ); R138892* (male) - $4.1 \mathrm{~km}$ south of Donkins Hill $\left(14.9875^{\circ} \mathrm{S} ; 125.5069^{\circ} \mathrm{E}\right)$; R167763* (female), R167764* (female), R167765* (male) - Little Mertens Falls, Mitchell Plateau $\left(14.8222^{\circ} \mathrm{S} ; 125.7108^{\circ} \mathrm{E}\right)$; R167807* (male) - Surveyors Pool, Mitchell Plateau $\left(14.6733^{\circ} \mathrm{S} ; 125.7322^{\circ} \mathrm{E}\right) ; \mathrm{R} 167866$ (female) - Mitchell Plateau $\left(14.8241^{\circ} \mathrm{S} ; 125.7181^{\circ} \mathrm{E}\right) ; \mathrm{R} 168151$ (male) and R168152* (female) - Prince Regent River Nature Reserve $\left(15.5944^{\circ} \mathrm{S} ; 125.1872^{\circ} \mathrm{E}\right)$; R168792 (male) Middle Osborn Island $\left(14.3166^{\circ} \mathrm{S} ; 126.0000^{\circ} \mathrm{E}\right)$; R171039 (female) - Uwins Island $\left(15.2580^{\circ} \mathrm{S} ; 124.7986^{\circ} \mathrm{E}\right)$; R171431 (male) - Monjon Rocks, Prince Regent River Nature Reserve (15.9808 ${ }^{\circ}$; $\left.125.3706^{\circ} \mathrm{E}\right)$; R171493 (male) - Prince Regent River Nature Reserve $\left(15.2947^{\circ} \mathrm{S}\right.$; $125.4950^{\circ} \mathrm{E}$ ); R171589 (male) - Little Mertens Falls, Mitchell Plateau $\left(14.8222^{\circ} \mathrm{S} ; 125.7106^{\circ} \mathrm{E}\right)$; R172063 (male) and R172064* (female), King Edward River $\left(14.8858^{\circ} \mathrm{S} ; 126.2033^{\circ} \mathrm{E}\right)$.

\section{Gehyra spheniscus sp. nov.}

R77018 (male) - Mertens Falls, Mitchell Plateau $\left(14.8166^{\circ} \mathrm{S} ; 125.7000^{\circ} \mathrm{E}\right)$; R83408 (male) - Galvans

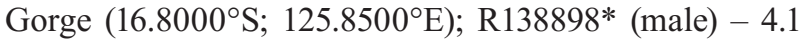
$\mathrm{km}$ south of Donkins Hill $\left(14.9875^{\circ} \mathrm{S} ; 125.5069^{\circ} \mathrm{E}\right)$; R168722 (juvenile) - Katers Island $\left(14.4666^{\circ} \mathrm{S}\right.$; $\left.125.5333^{\circ} \mathrm{E}\right)$; R171506 (female) - Prince Regent River Nature Reserve $\left(15.7616^{\circ} \mathrm{S} ; 125.2561^{\circ} \mathrm{E}\right)$; R171592 (female) - Lower Monjon Rocks, Prince Regent River Nature Reserve $\left(15.9786^{\circ} \mathrm{S} ; 125.3672^{\circ} \mathrm{E}\right)$.

\section{Gehyra occidentalis}

R158042 (male; $16.1216^{\circ} \mathrm{S} ; 123.7200^{\circ} \mathrm{E}$ ) and R158997 (male; $\left.16.1194^{\circ} \mathrm{S} ; 123.7275^{\circ} \mathrm{E}\right)$ - Koolan Island; R164773-5*** (females) - Mt Nyulasy $\left(16.7452^{\circ} \mathrm{S}\right.$; $\left.128.2825^{\circ} \mathrm{E}\right)$; R168079 and R168194 (female) - Prince

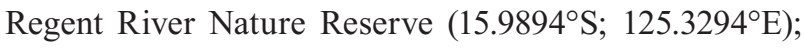
R168447 (male) - Irvine Island $\left(16.0755^{\circ} \mathrm{S} ; 123.5508^{\circ} \mathrm{E}\right)$; R172076* (male) - NW Molema Island (16.2541 ${ }^{\circ} \mathrm{S}$; $123.8244^{\circ} \mathrm{E}$ ); R172094 (male) - Wulalam Island $\left(16.3680^{\circ} \mathrm{S} ; 124.2303^{\circ} \mathrm{E}\right)$.

\section{Gehyra multiporosa sp. nov.}

R46883 (male) - Prince Regent River Nature Reserve (15.1166 ${ }^{\circ}$ S; $\left.125.5500^{\circ} \mathrm{E}\right)$; R167855* (male) - Mitchell Plateau $\left(14.8258^{\circ} \mathrm{S} ; 125.7208^{\circ} \mathrm{E}\right) ; \mathrm{R} 168581$ (female) - Jungulu (Darcy) Island $\left(15.2833^{\circ} \mathrm{S} ; 124.3833^{\circ} \mathrm{E}\right)$; R172068 (female) - Storr Island $\left(15.9500^{\circ} \mathrm{S} ; 124.5611^{\circ} \mathrm{E}\right)$.

APPENDIX 2 Additional specimens included in the molecular genetic analysis (not listed in the type lists or Appendix 1). Abbreviations: South Australian Museum, Adelaide (SAMA); Western Australian Museum, Perth (WAM).

\section{Gehyra xenopus}

SAMA R53962 - Cape Voltaire $\left(14.3500^{\circ} \mathrm{S}\right.$; $\left.125.5833^{\circ} \mathrm{E}\right)$; WAM R167808-9 - as for WAM R167807, Appendix 1); WAM R168051 - Quail Falls $\left(15.7483^{\circ} \mathrm{S}\right.$; $\left.125.3736^{\circ} \mathrm{E}\right)$.

\section{Gehyra spheniscus sp. nov.}

WAM R171506 - Prince Regent Nature Reserve $\left(15.7616^{\circ} \mathrm{S} ; 125.2561^{\circ} \mathrm{E}\right)$.

\section{Gehyra occidentalis}

WAM R146018 - Kimbolton homestead (16.6833 ${ }^{\circ}$; $\left.123.8333^{\circ} \mathrm{E}\right)$; WAM R168079, WAM R168194 - Bachsten Creek (15.9894 ${ }^{\circ}$ S; $\left.125.3294^{\circ} \mathrm{E}\right)$; WAM R172070, WAM R172089, WAM R172092, WAM R172106 - Manning Gorge $\left(16.6555^{\circ} \mathrm{S} ; 125.9261^{\circ} \mathrm{E}\right)$; WAM R172086 Long Island $\left(16.5575^{\circ} \mathrm{S} ; 123.3553^{\circ} \mathrm{E}\right)$; WAM R172097 - Lachlan Island $\left(16.6225^{\circ} \mathrm{S} ; 123.4714^{\circ} \mathrm{E}\right)$; WAM R172112 - Adcock Gorge, Phillips Range (16.8850 ${ }^{\circ} \mathrm{S}$; $\left.125.8039^{\circ} \mathrm{E}\right)$; WAM R172140 (16.0816 $\left.{ }^{\circ} \mathrm{S} ; 124.0750^{\circ} \mathrm{E}\right)$, WAM R172143 $\left(16.0816^{\circ} \mathrm{S} ; 124.0706^{\circ} \mathrm{E}\right)$, WAM R172144 $\left(16.0925^{\circ} \mathrm{S} ; 124.0931^{\circ} \mathrm{E}\right)-$ Kingfisher Island.

\section{Gehyra multiporosa sp. nov.}

SAMA R53963 - Cape Voltaire $\left(14.3500^{\circ} \mathrm{S}\right.$; $\left.125.5833^{\circ} \mathrm{E}\right)$; WAM R83712 $\left(14.8833^{\circ} \mathrm{S} ; 125.7500^{\circ} \mathrm{E}\right)$, WAM R117901 $\left(14.9116^{\circ} \mathrm{S} ; 126.0517^{\circ} \mathrm{E}\right)$ - Mitchell Plateau; WAM R96949 - Mt Trafalger $\left(15.2805^{\circ} \mathrm{S}\right.$; $\left.125.0681^{\circ} \mathrm{E}\right)$; WAM R113968-9 - Old Theda $\left(14.8166^{\circ} \mathrm{S} ; 126.5000^{\circ} \mathrm{E}\right)$; WAM R168148-9 - Camp Creek $\left(15.5944^{\circ} \mathrm{S} ; 125.1872^{\circ} \mathrm{E}\right)$; WAM R168582 Coronation Island $\left(14.9833^{\circ} \mathrm{S} ; 124.9167^{\circ} \mathrm{E}\right)$; WAM R168587 - St Andrew Island (15.3500 $\left.{ }^{\circ} \mathrm{S} ; 125.0000^{\circ} \mathrm{E}\right)$; WAM R168711, WAM R168732 - Katers Island

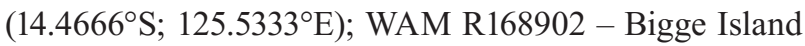
$\left(14.6000^{\circ} \mathrm{S} ; 125.1167^{\circ} \mathrm{E}\right) ;$ WAM R171501 - Harding Range (14.4666 $\left.{ }^{\circ} \mathrm{S} ; 125.5333^{\circ} \mathrm{E}\right)$; WAM R172066 - Storr Island $\left(15.9508^{\circ} \mathrm{S} ; 124.5617^{\circ} \mathrm{E}\right)$.

\section{Gehyra nana}

WAM R172173-4 - King Edward River (type location; $\left.14.8852^{\circ} \mathrm{S} ; 126.2042^{\circ} \mathrm{E}\right)$. 